\title{
CHLORINE DIOXIDE AGAINST BACTERIA AND YEASTS FROM THE ALCOHOLIC FERMENTATION
}

\author{
Silvana Perissatto Meneghin ${ }^{1,2 *}$; Fabricia Cristina Reis ${ }^{1}$; Paulo Garcia de Almeida ${ }^{3}$; Sandra Regina Ceccato-Antonini ${ }^{4}$ \\ ${ }^{1}$ Departamento de Biotecnologia Vegetal, Centro de Ciências Agrárias, Universidade Federal de São Carlos, Araras, SP, Brasil; \\ ${ }^{2}$ Universidade Estadual Paulista, Microbiologia Aplicada, Rio Claro, SP, Brasil; ${ }^{3}$ Beraca Sabará Químicos e Ingredientes Ltda, \\ Unidade São Paulo, São Paulo, SP, Brasil; ${ }^{4}$ Departamento de Tecnologia Agroindustrial e Sócio-Economia Rural, Centro de \\ Ciências Agrárias, Universidade Federal de São Carlos, Araras, SP, Brasil
}

Submitted: July 12, 2007; Returned to authors for corrections: October 27, 2007; Approved: April 25, 2008.

\begin{abstract}
The ethanol production in Brazil is carried out by fed-batch or continuous process with cell recycle, in such way that bacterial contaminants are also recycled and may be troublesome due to the substrate competition. Addition of sulphuric acid when inoculum cells are washed can control the bacterial growth or alternatively biocides are used. This work aimed to verify the effect of chlorine dioxide, a well-known biocide for bacterial decontamination of water and equipments, against contaminant bacteria (Bacillus subtilis, Lactobacillus plantarum, Lactobacillus fermentum and Leuconostoc mesenteroides) from alcoholic fermentation, through the method of minimum inhibitory concentration (MIC), as well as its effect on the industrial yeast inoculum. Lower MIC was found for B. subtilis (10 ppm) and Leuconostoc mesenteroides (50 ppm) than for Lactobacillus fermentum (75 ppm) and Lactobacillus plantarum (125 ppm). Additionally, these concentrations of chlorine dioxide had similar effects on bacteria as 3 ppm of Kamoran ${ }^{\circledR}$ (recommended dosage for fermentation tanks), exception for B. subtilis, which could not be controlled at this Kamoran ${ }^{\circledR}$ dosage. The growth of industrial yeasts was affected when the concentration of chlorine dioxide was higher than $50 \mathrm{ppm}$, but the effect was slightly dependent on the type of yeast strain. Smooth yeast colonies (dispersed cells) seemed to be more sensitive than wrinkled yeast colonies (clustered cells/pseudohyphal growth), both isolated from an alcoholproducing unit during the 2006/2007 sugar cane harvest. The main advantage in the usage of chlorine dioxide that it can replace antibiotics, avoiding the selection of resistant populations of microorganisms.
\end{abstract}

Key words: chlorine dioxide, bacteria, yeast, antibacterial agent, alcohol, fermentation.

\section{INTRODUCTION}

Chlorine dioxide $\left(\mathrm{ClO}_{2}\right)$ has been extensively used in gaseous form for bacterial decontamination, which is a more effective disinfectant than free chlorine $(8,18)$. Since the early 1900 s free chlorine has been applied to drinking water systems, however, it can react with natural organic matter forming disinfection byproducts, DBPs (15), which consequently led the water industry to seek for alternative disinfectants.

Chlorine dioxide is a strong oxidant, used for the control of iron, manganese and taste and odor causing compounds.
It has excellent bactericide, viruscide, sporicide and algaecide properties and by these reasons, it is used also as a disinfectant for municipal sewage and as an algal growing inhibitor. Its oxidizing and disinfectious properties are kept within a wide $\mathrm{pH}$ range (4 to 10) and it is highly water-soluble. The most remarkable characteristics of chlorine dioxide is its ability to oxidize other substances through a transfer mechanism of only an electron, when the dioxide is reduced to chlorite without hypochlorite or gaseous chlorine production (9). For this reason, it shows reduced formation of organochloride products and besides it does not react with ammonia preventing chloramine

*Corresponding Author. Mailing address: Via Anhanguera, km 174 - CEP: 13600-970. Araras, SP, Brasil. Tel./Fax: (+5519) 3543-2612. E-mail: silvana.meneghin@cca.ufscar.br 
formation, which is potentially toxic. Studies have shown that chlorine and chlorate can be formed, however, in low concentrations, with no risk to human health when chlorine dioxide is used for drinking water systems (21).

It has been used as a secondary disinfectant in several European countries, including Italy, Germany, France and Switzerland (7). Usage as bleach in textile industry and antifouling agent in water systems is also recommended for chlorine dioxide (4). Though its strong effect against bacteria, it has been shown to have a degree of fungicidal activity in solution (12), especially against some mold growth (19). Authors (13) have found that the marine yeast Debaryomyces hansenii is highly tolerant to chlorine dioxide, in such a way that helped to avoid the growth of unwanted microorganisms while allowing the yeast development. Disinfectants containing chloride and persulphate were ineffective in destroying yeast cells both in suspensions and in biofilm formations (16).

Yeast and bacteria can compete by the same substrate during the fermentative process for alcohol production, mainly because the fermentation is carried out in fed-batch or continuous process with cell recycling. Lactic acid bacteria as Lactobacillus and Leuconostoc are commonly found in alcoholic fermentation and always associated with problems in the process (2). According to Rodini (14), Gram-positive bacteria account for $65 \%$ of total number, with $62 \%$ belonging to genus Bacillus ( $B$. subtilis, B. megaterium, B. coagulans). It has been found genera Lactobacillus, Leuconostoc and Bacillus in the proportions of $38 \%, 12 \%$ e $3 \%$, respectively, in sugar cane juice after clarification, pasteurization and cooling processes (17). The contaminant control is extremely important to obtain high yields during the process, because the presence of these bacteria may reduce yeast viability $(6,11)$.

Lactobacillus is highly adapted to nutritional conditions and to alcoholic concentration, however, the genus Leuconostoc is more sensitive to ethanol and has short-life duration inside the tanks. Besides acid production, Lactobacillus causes serious yeast flocculation problems, resulting in viability decrease of Saccharomyces cerevisiae during fermentation $(6,20)$.

Bacterial growth is industrially controlled by the addition of sulphuric acid when yeast cells are washed after fermentation. Biocides are sometimes required to be added to sugar cane juice, such as carbamates, quaternary compounds, halogenated phenols and antibiotics. Their high cost, need for periodic application and selection of resistant microorganisms by antibiotics are the major weak points concerning the use of these biocides. For this reason, bacterial contamination in number of $10^{5} \mathrm{CFU} / \mathrm{ml}$ is an acceptable limit for alcohol operating units, not economically viable the act of reducing this level (1). So, this work aimed the evaluation of chlorine dioxide as a biocide against contaminant bacteria and yeasts from the alcoholic fermentation through the usage of minimum inhibitory concentration methodology. Saving, efficiency and avoidance of by-side effects are beneficial points that have been considered in the use of this biocide.

\section{MATERIALS AND METHODS}

\section{Microorganisms and growth curves}

The following bacterial strains were used in experiments, from Fundação André Tosello - Coleção de Culturas Tropical, Campinas - SP - Brasil: CCT 2471 (ATCC 6051) - Bacillus subtilis; CCT 0559 (ATCC 9338) - Lactobacillus fermentum; CCT 5852 (ATCC 19255) - Leuconostoc mesenteroides; CCT 0580 (ATCC 8014) - Lactobacillus plantarum. They were inoculated in appropriate culture media (MRS for Lactobacillus, at $37^{\circ} \mathrm{C}$; Nutrient Agar $/$ Broth for the others, at $30^{\circ} \mathrm{C}$ ) and kept at $4^{\circ} \mathrm{C}$. Initially the growth curves of all bacteria were established using culture media and temperature above in order to detect the log growth phase. 500 -ml flasks with $100 \mathrm{ml}$ of culture medium were inoculated with two loops of each bacteria, keeping the flasks at $30^{\circ} \mathrm{C}$ or $37^{\circ} \mathrm{C}$ (depending on the strain), $160 \mathrm{rpm}$ of shaking, for 30 hours, with periodical sampling and analysis of optical density at $540 \mathrm{~nm}$ in a spectrophotometer Thermo ${ }^{\circledR}$ Biomate 3.

\section{Biocide preparation}

The stock solution of chlorine dioxide (Diox ${ }^{\circledR}, 5 \% \mathrm{w} / \mathrm{vol}$, from "Beraca Sabará") was prepared as following: initially, $1 \mathrm{ml}$ was transferred aseptically to $9 \mathrm{ml}$ of sterile distilled water in a glass tube. The content $(10 \mathrm{ml})$ was sequentially transferred to a flask containing $70 \mathrm{ml}$ of sterile distilled water and homogenized (final $\mathrm{ClO}_{2}$ concentration was $625 \mathrm{ppm}$ ). Product specifications can be found in reference 4 .

\section{Minimum inhibitory concentration (MIC) of chlorine dioxide for bacteria}

The experiments were carried out in sterile 50-ml Falcon tubes containing $10 \mathrm{ml}$ of final volume, with $9 \mathrm{ml}$ of culture medium (MRS or Nutrient Broth), $0.2 \mathrm{ml}$ of the bacterial inoculum in log phase, chlorine dioxide in stock solution in a quantity dependent on the dosage tested and saline solution $(0.85 \%$ $\mathrm{NaCl}$ solution) to complete the final volume. Triplicates for each treatment were prepared and maintained at $30^{\circ} \mathrm{C}$ or $37^{\circ} \mathrm{C}$, depending on the strain, for 24 hours, following by the optical density determination at $540 \mathrm{~nm}$, using non-inoculated medium as reaction blank. Three control treatments were used: culture medium + saline solution, culture medium + saline solution + biocide (lowest concentration), culture medium + saline solution + biocide (highest concentration), always keeping $10 \mathrm{ml}$ as final volume. Concentrations of chlorine dioxide ranging from 1 to $200 \mathrm{ppm}$ were utilized, depending on the bacterial strain. Experiments were repeated at least twice. The biocide Kamoran ${ }^{\circledR}$ at 3 ppm was used for comparison. 
Log-phase bacterial inoculum was as following $\left(\mathrm{OD}_{540} /\right.$ cultivation time): Bacillus subtilis, 0.7 / 16h; Leuconostoc mesenteroides, 1.1 / 14h; Lactobacillus plantarum, 0.7 / 14h; Lactobacillus fermentum, $1.1 / 9 \mathrm{~h}$.

\section{Minimum inhibitory concentration (MIC) of chlorine dioxide for yeasts}

Initially tests were performed in Petri dishes with WL Nutrient Medium (Acumedia Manufacturers, Inc. Lansing, Michigan) added with ampicilin (5 ppm) and nalidixic acid (5 ppm) to avoid bacterial growth, inoculated with diluted aliquots of fermented must sampled from fermentation tanks at Usina Santa Lúcia, Araras, SP, 2006/2007 sugar cane harvest. Chlorine dioxide was added to the medium in concentrations of 50,100 and $200 \mathrm{ppm}$. Yeast colonies developed in WLN medium without chlorine dioxide were purified in YEPD medium and individually tested for MIC as described for bacteria. Yeast inocula were prepared in $10 \mathrm{ml}$ of liquid YEPD medium, at $30^{\circ} \mathrm{C}, 160 \mathrm{rpm}$ of shaking, overnight, inoculated with two loops of cells. After centrifugation and washing with sterilized saline solution, the cells were resuspended in saline solution and the suspension was used as inoculum for MIC tests as described before, but for optical density determination, which was $600 \mathrm{~nm}$.

\section{Statistical analysis}

One-way analysis of variance and Tukey test at $95 \%$ of confidence level were performed in all experiments using data analysis at Microsoft ${ }^{\circledR}$ Excel software.

\section{RESULTS AND DISCUSSION}

Initially, chlorine dioxide was used as antibacterial agent in concentrations of 10, 25 and $50 \mathrm{ppm}$ for all bacterial strains. However, MIC was observed to be probably under $10 \mathrm{ppm}$ for
B. subtilis. Subsequent tests with lower concentrations confirmed that $10 \mathrm{ppm}$ was the lowest concentration of chlorine dioxide to inhibit this bacterium, with remarkable growth decrease in the range of 1 to $10 \mathrm{ppm}$. With Kamoran ${ }^{\circledR}$, the recommended concentration for usage in fermentation tanks ( $3 \mathrm{ppm}$ ) was not efficient to suppress B. subtilis growth (Fig. 1).

All control treatments (without inoculum) had $\mathrm{OD}_{540}$ variying from 0.01 to 0.02 after 24 hours of cultivation.

With Leuconostoc mesenteroides, $50 \mathrm{ppm}$ of chlorine dioxide was the MIC, with complete absence of growth, showing remarkable decrease of growth in the range of 10 to $50 \mathrm{ppm}$. Other than B. subtilis, dosage of 3 ppm of Kamoran ${ }^{\circledR}$ caused significant reduction, but not cessation of growth as chlorine dioxide did (Fig. 2).

Concerning Lactobacillus plantarum, the experiments were performed at $37^{\circ} \mathrm{C}$, and concentrations ranging from 10,25 and $50 \mathrm{ppm}$ of chlorine dioxide did not inhibit bacterial growth. Concentration in the range of 100-200 ppm of chlorine dioxide was then efficient to prevent growth, as well as $3 \mathrm{ppm}$ of Kamoran ${ }^{\circledR}$. Statistical analysis has shown that $125 \mathrm{ppm}$ of chlorine dioxide had similar inhibitory effect to that obtained with 150 and 200 ppm (Fig. 3).

Total inhibition of growth was obtained with $100 \mathrm{ppm}$ of chlorine dioxide for Lactobacillus fermentum, similarly to that result for 3 ppm of Kamoran ${ }^{\circledR}$ (Fig. 4), both experiments at $37^{\circ} \mathrm{C}$. However, statistically significant result was obtained using 75 ppm of chlorine dioxide. Previous studies have shown that the genus Lactobacillus is more adapted to the fermentative process conditions (10), and so, more resistant to antimicrobial agents.

In order to verify whether chlorine dioxide has inhibitory effect on yeast, which would impair its usage as biocide in alcoholic fermentation, fermented must collected from an alcoholoperating unity at 2006/2007 sugar cane harvest was tested using

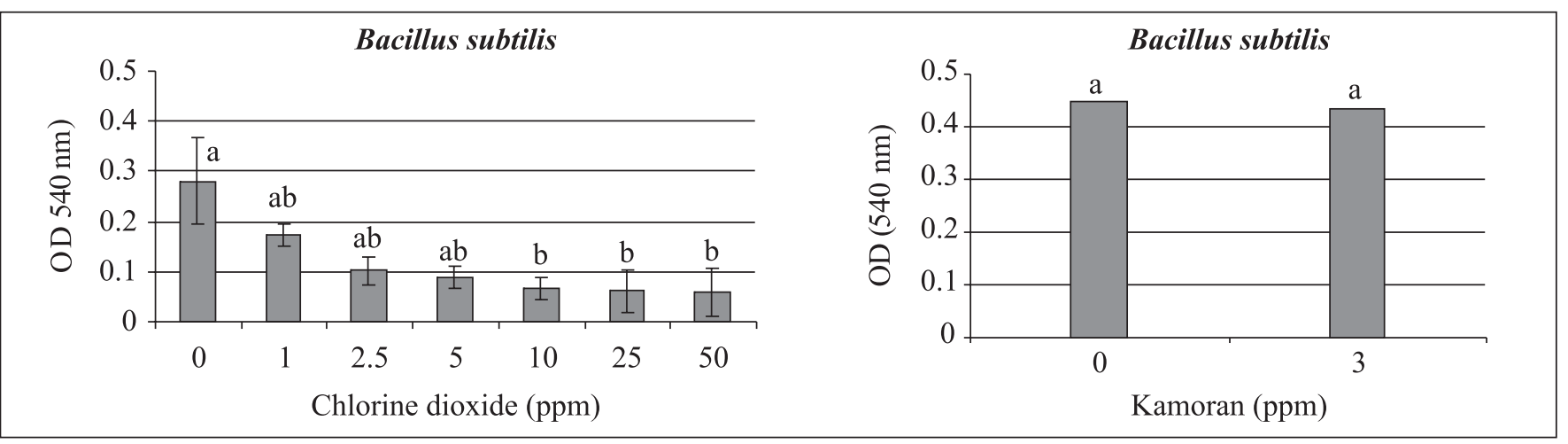

Figure 1. Average and standard error (vertical lines) of B. subtilis growth at $30^{\circ} \mathrm{C}$, after 24 hours of cultivation in Nutrient broth, in

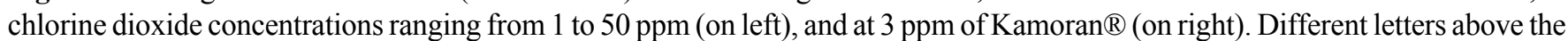
bars mean significant difference at $95 \%$ of confidence level. 


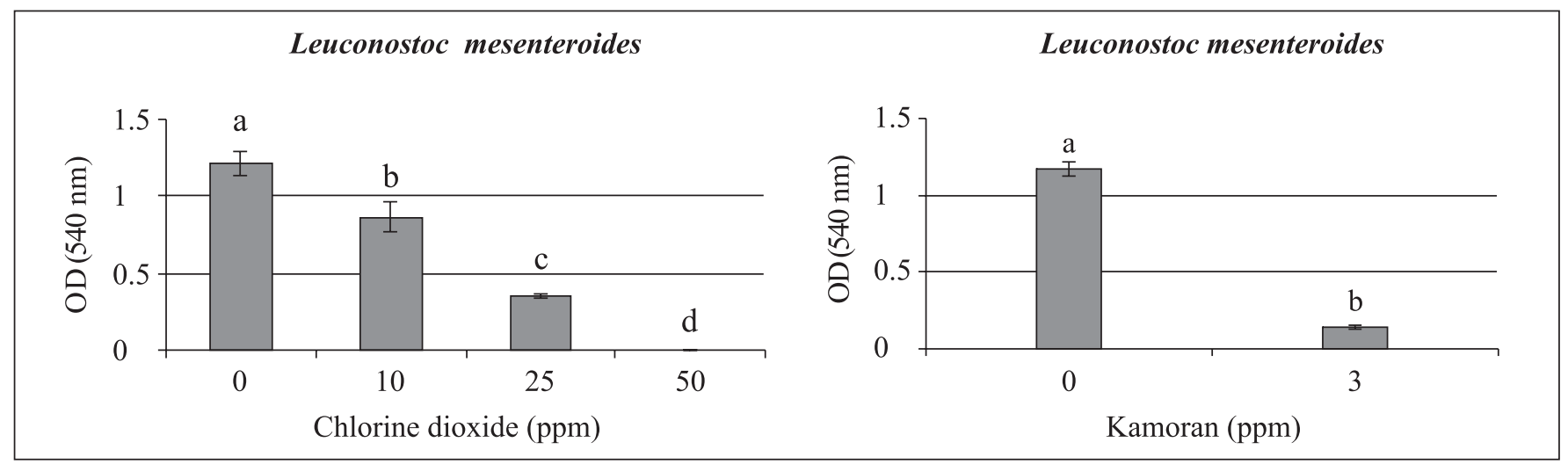

Figure 2. Average and standard error (vertical lines) of Leuconostoc mesenteroides growth at $30^{\circ} \mathrm{C}$, after 24 hours of cultivation in Nutrient broth, in chlorine dioxide concentrations ranging from 1 to 50 ppm (on left), and at 3 ppm of Kamoran ${ }^{\circledR}$ (on right). Different letters above the bars mean significant difference at $95 \%$ of confidence level.

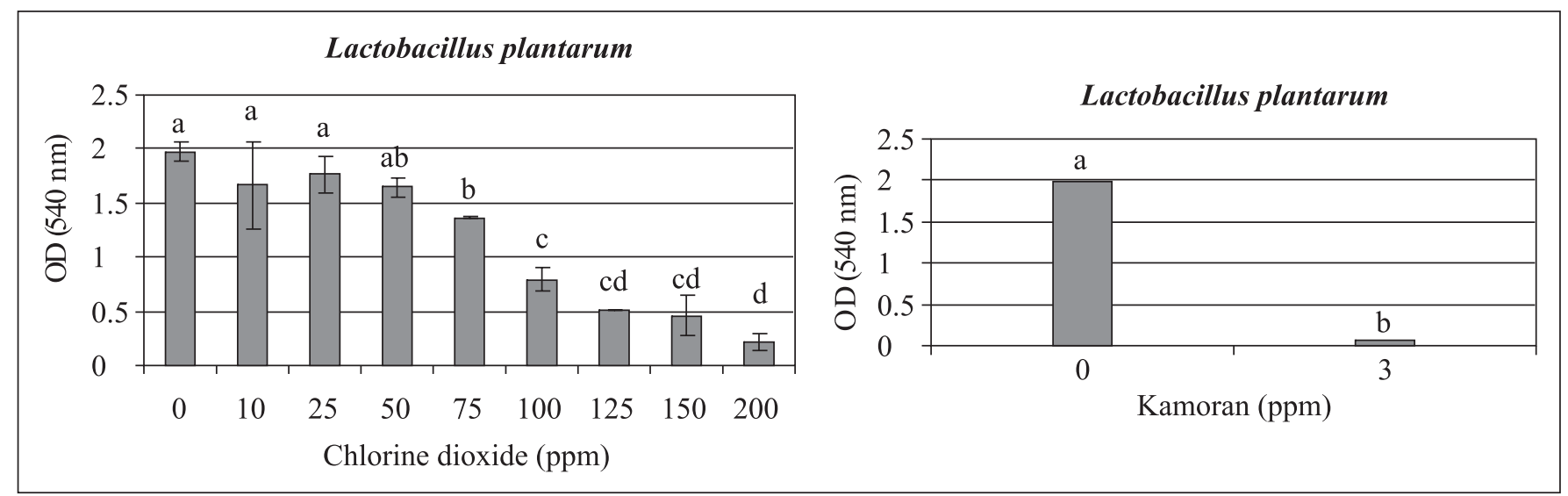

Figure 3. Average and standard error (vertical lines) of Lactobacillus plantarum growth at $37^{\circ} \mathrm{C}$, after 24 hours of cultivation in MRS broth, in chlorine dioxide concentrations ranging from 10 to $200 \mathrm{ppm}$ (on left), and at 3 ppm of Kamoran ${ }^{\circledR}$ (on right). Different letters above the bars mean significant difference at $95 \%$ of confidence level.

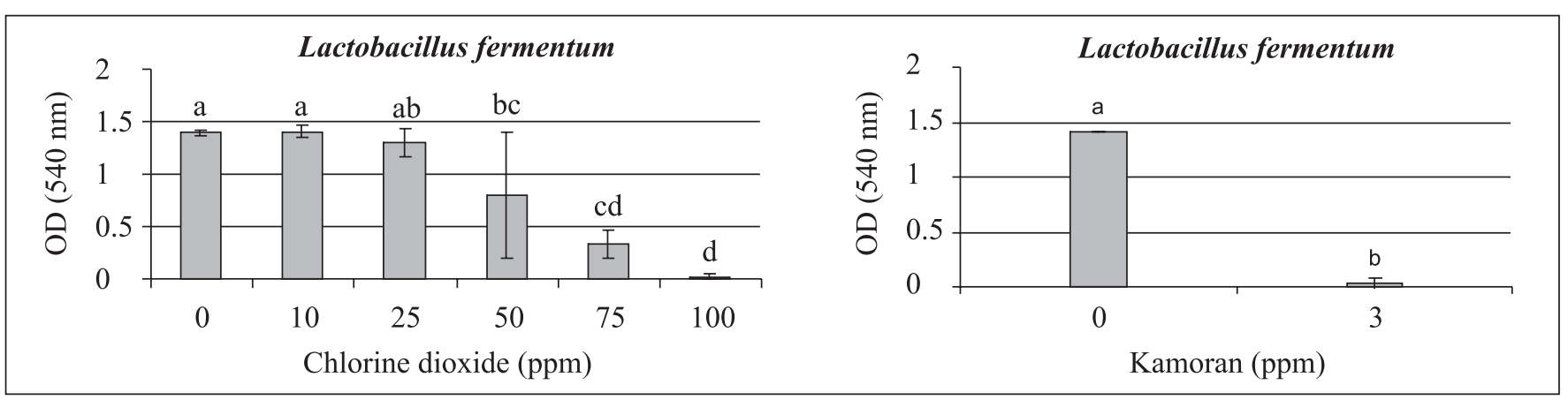

Figure 4. Average and standard error (vertical lines) of Lactobacillus fermentum growth at $37^{\circ} \mathrm{C}$, after 24 hours of cultivation in MRS broth, in chlorine dioxide concentrations ranging from 10 to 100 ppm (on left), and at 3 ppm of Kamoran ${ }^{\circledR}$ (on right). Different letters above the bars mean significant difference at $95 \%$ of confidence level. 
plating and serial dilution techniques, in concentrations of 50, 100 and 200 ppm of chlorine dioxide. The yeast growth was completely inhibited at $100 \mathrm{ppm}$, but at $50 \mathrm{ppm}$ of chlorine dioxide, the number of colony forming units was three times lower than in control dishes (with no chlorine dioxide), as in Fig. 5. This reduction may be considered low because of the high numbers of yeast cells present into fermentation tanks (around $10^{8}$ cells/ $\mathrm{ml}$ ) and did not reach even one-log order decrease.

Two different yeast colonies were observed in culture medium, as smooth, bright colonies; and wrinkled, opaque colonies. They were isolated, purified and tested individually in tubes for MIC detection, similarly to the methodology used for bacterial strains, using chlorine dioxide concentrations ranging from 0 to $200 \mathrm{ppm}$. Cells from the wrinkled colony were slightly more resistant than the ones from the smooth colonies (Fig. 6), though the difference was not statistically significant.

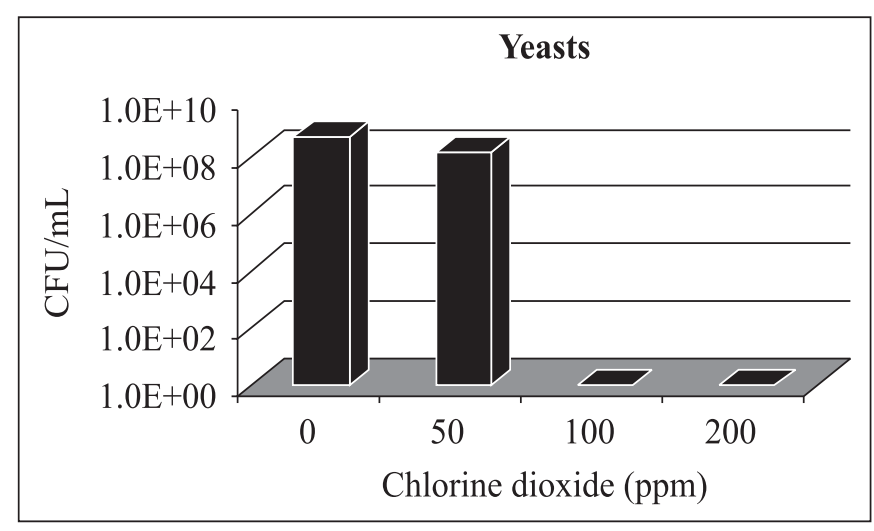

Figure 5. Yeast colony forming units $/ \mathrm{ml}$ from the inoculum of the alcoholic fermentation, in WLN medium, in chlorine dioxide concentrations ranging from 50 to $200 \mathrm{ppm}$.

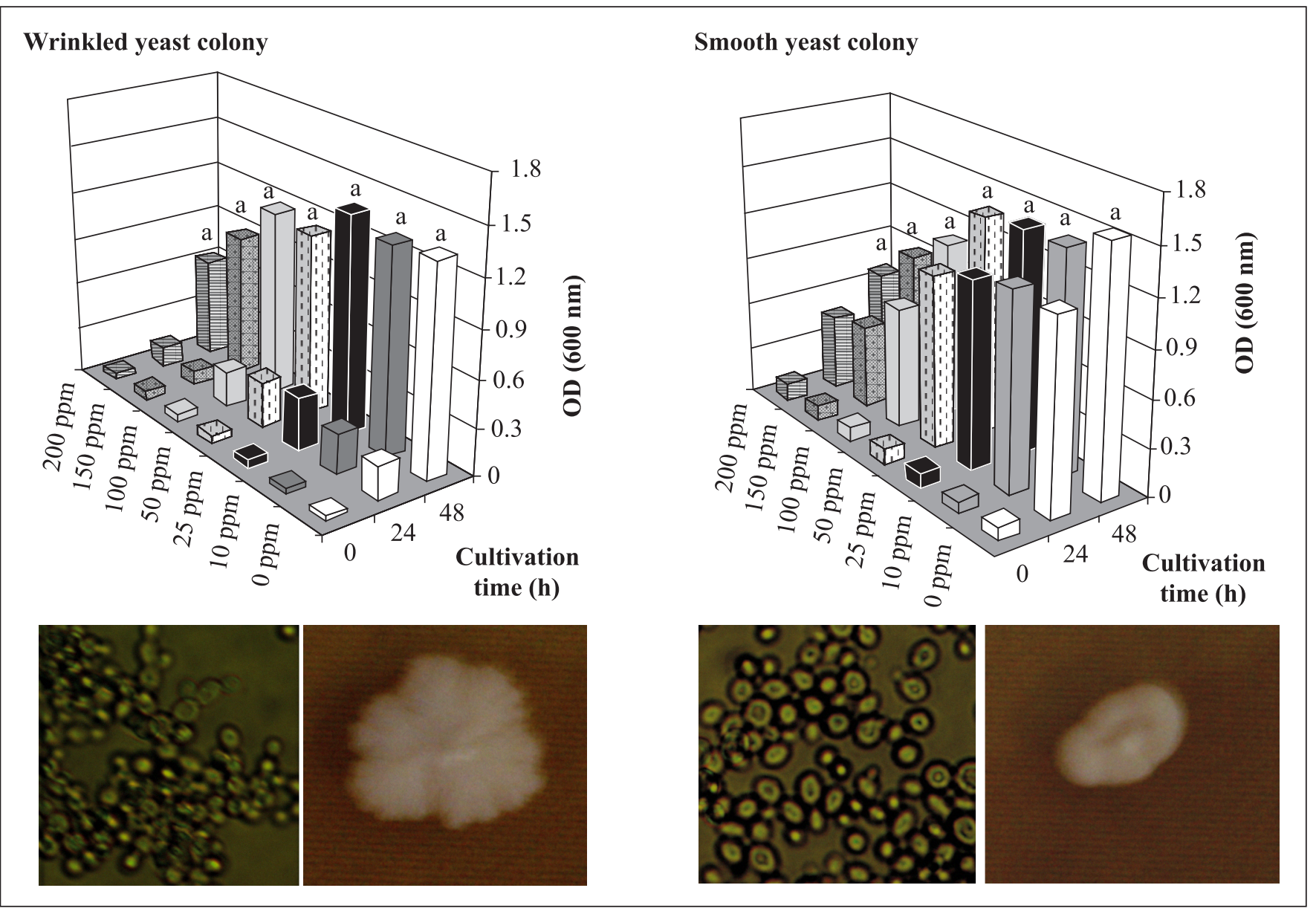

Figure 6. Yeast growth of strains (wrinkled and smooth colonies) isolated from the inoculum of the alcoholic fermentation, at $30^{\circ} \mathrm{C}$ in YEPD medium, in chlorine dioxide concentrations ranging from 10 to $200 \mathrm{ppm}$. Different letters above the bars mean significant difference at 95\% of confidence level. Photographies of yeast cells (left, 400X magnification) and yeast colonies (right, on YEPD plates) are seen on each panel. 
For wrinkled yeast colonies, there was a decrease in growth from $150 \mathrm{ppm}$ while for smooth yeast colonies, $100 \mathrm{ppm}$ was enough to cause the same effect. Total growth inhibition was not observed in the chlorine dioxide range studied for both yeasts, as observed when plating technique was used. A probable explanation is the fact that plating technique is a measure of viable cells, which are not distinguished from dead cells using optical density as growth evaluation.

Yeasts presenting clustered cells, as pseudohyphae, are very common in alcoholic fermentation process, and though they are related to poor fermentative performance (3), this cell arrangement can confer protection against undesirable environment, in a process called filamentation (5). Further studies are needed to assess the supposed higher resistance to chlorine dioxide by the wrinkled yeast colonies.

For the safe usage of chlorine dioxide as antibacterial agent in alcoholic fermentation, it is not advisable to utilize more than $50 \mathrm{ppm}$ in order to avoid harmful effects on the yeast inoculum. However, Lactobacillus bacteria had presented minimum inhibitory concentration for chlorine dioxide above $50 \mathrm{ppm}$.

Further studies are encouraged since activation in $\mathrm{pH}$ below 4 brought about more efficiency, demanding lower dosages than those recommended here (unpublished data). Besides, other important characteristics should be considered for chlorine dioxide: approval at USDA Organic for application in organic products; prevention of resistance occurrence in bacterial populations by the use of antibiotics; higher profits with the sales of yeast for feed since antibiotics are not allowed; saving of sulphuric acid, once chlorine dioxide has anti-buffering effect when applied to the inoculum production step; besides antibiotics replacing, chlorine dioxide also eliminated the usage of other antibacterial agents.

\section{ACKNOWLEDGMENTS}

The authors wish to thank Dr. Norberto Antonio Lavorenti (UFSCar) for his helpful assistance in statistical analysis.

\section{RESUMO}

\section{Dióxido de cloro contra bactérias e leveduras da fermentação alcoólica}

A produção de etanol no Brasil é atualmente realizada pelo processo de fermentação em batelada alimentada ou contínuo, com reciclo de células de leveduras, de forma que contaminantes bacterianos são também reciclados e podem causar problemas devido à competição pelo mesmo substrato. $\mathrm{O}$ controle bacteriano é feito pela adição de ácido sulfúrico na lavagem das células do fermento ou utilizando-se biocidas. $\mathrm{O}$ objetivo do trabalho foi verificar o efeito do dióxido de cloro, um biocida muito utilizado para a descontaminação da água e equipamentos, contra bactérias contaminantes da fermentação alcoólica (Bacillus subtilis, Lactobacillus plantarum, Lactobacillus fermentum e Leuconostoc mesenteroides), através do método da concentração inibitória mínima (CIM), assim como seu efeito sobre o fermento industrial. Valores menores de CIM foram encontrados para Bacillus subtilis (10 ppm) e Leuconostoc mesenteroides (50 ppm) do que para Lactobacillus fermentum (75 ppm) e Lactobacillus plantarum (125 ppm). Estas concentrações tiveram o mesmo efeito inibidor que $3 \mathrm{ppm}$ de Kamoran ${ }^{\circledR}$, com exceção de $B$. subtilis, no qual não se observou inibição de crescimento à esta concentração. As leveduras industriais apresentaram inibição no crescimento em concentrações superiores a $50 \mathrm{ppm}$, porém esta pareceu ser dependente do tipo de linhagem de levedura. Colônias cremosas (células dispersas) foram ligeiramente mais sensíveis que as colônias rugosas (células agrupadas/pseudohifas), ambas isoladas de uma unidade produtora de álcool durante a safra de cana-de-açúcar 2006/2007. A principal vantagem na utilização deste produto está na eliminação do uso de antibióticos, evitando a geração de populações resistentes de microrganismos.

Palavras-chave: fermentação alcoólica, bactérias contaminantes, dióxido de cloro, leveduras

\section{REFERENCES}

1. Alcarde, A.R.; Walder, J.M.M.; Horii, J. (2003). Fermentation of irradiated sugarcane must. Scientia Agricola, 60 (4), 677-681.

2. Amorim, H.V.; Oliveira, A.J. (1982). Infecção na fermentação: como evitá-la. Álcool e Açúcar, 2 (5), 12-18.

3. Basso, L.C.; Paulillo, S.C.L.; Amorim, H.V.; Lopes, M.L.; Oliveira, A.J. (2005). Impacto das leveduras selvagens sobre o processo industrial de produção de etanol. XXIII Congresso Brasileiro de Microbiologia, Santos-SP. (CD-rom).

4. Beraca Sabará - Divisão Sanitizantes. (2007). Available at: http:// www.sanitizantes.com.br/br/diox.php. Accessed 15 June 2007.

5. Ceccato-Antonini, S.R.; Sudbery, P.E. (2004). Filamentous growth in Saccharomyces cerevisiae. Braz. J. Microbiol., 35 (3), 173-181.

6. Cherubin, R.A. (2005). Efeitos da viabilidade da levedura e da contaminação bacteriana na fermentação alcoólica. Piracicaba, SP, Brasil. (M.Sc. Dissertation. ESALQ/USP).

7. Dernat, M.; Leburgue, A.; Oliveira, D.; Gauthierand, J.P.; Pouillot, M. (1995). Chlorine dioxide: a European perspective. III International Symposium on Chlorine Dioxide, New Orleans, LA.

8. Han, Y.; Applegate, R.H.; Linton, R.H.; Nelson, P.E. (2003). Decontamination of Bacillus thuringiensis spores on selected surfaces by chlorine dioxide gas. J. Environ. Health, 66, 16-21.

9. Lapolli, F.R.; Hassemer, M.E.N.; Camargo, J.G.; Damásio, D.L.; LoboRecio, M.A. (2005). Desinfecção de efluentes sanitários através de dióxido de cloro. Eng. Sanit. Ambient., 10 (3), 200-208.

10. Narendranath, N.V.; Power, R. (2004). Effect of yeast inoculation rate on the metabolism of contaminating lactobacilli during fermentation of corn mash. J. Ind. Microbiol., 31, 581-584.

11. Nobre, T.P. (2005). Viabilidade celular de Saccharomyces cerevisiae cultivada em associação com bactérias contaminantes da fermentação alcoólica. Piracicaba, SP, Brasil. (M.Sc. Dissertation. ESALQ/USP).

12. Price, D.L.; Ahearn, D.G. (1999). Sanitation of wallboard colonized with Stachybotrys chartarum. Curr. Microbiol., 39, 21-26. 
13. Ramirez-Orozco, M.; Hernández-Saavedra, N.Y.; Ochoa, J.L. (2001). Debaryomyces hansenii growth in nonsterile seawater $\mathrm{ClO}_{2}$-peptonecontaining medium. Can. J. Microbiol., 47 (7), 676-679.

14. Rodini, M.A.T. (1985). Isolamento, caracterização e identificação de bactérias contaminantes de dornas de fermentação nas destilarias de etanol. Piracicaba, SP, Brasil (M.Sc. Dissertation, ESALQ/USP).

15. Rooks, J.J. (1977). Haloforms in drinking water. J. Am. Water Works Assoc., 68 (3), 168-172.

16. Salo, S.; Wirtanen, G. (2005). Disinfectant efficacy on foodborne spoilage yeast strains. Trans. ChemE, Part C, Food Bioprod. Process., 83 (C4), 288-296.

17. Silva, N. (1988). Influência do resfriamento em torres sobre a microflora do caldo de cana no processo de produção de álcool. Campinas, SP, Brasil (M.Sc. Dissertation, Unicamp).
18. Volk, C.J.; Hofmann, R.; Chauret, C.; Gagnon, G.A.; Ranger, G.; Andrews, R.C. (2002). Implementation of chlorine dioxide disinfection: effects of the treatment change on drinking water quality in a full-scale distribution system. J. Environ. Eng. Sci., 1, 323-330.

19. Wilson, S.C.; Wu, C.; Andriychuk, L.A.; Martin, J.M.; Brasel, T.L.; Jumper, C.A.; Straus, D.C. Effect of chlorine dioxide gas on fungi and mycotoxins associated with sick building syndrome. Appl. Environ. Microbiol., 71 (9), 5399-5403.

20. Yokoya, F.; Oliva-Neto, P. (1991). Características da floculação de leveduras por Lactobacillus fermentum. Rev. Microbiol., 22 (1), $12-16$

21. Zavaletta, O. (1992). Chlorine dioxide risk assessment for drinking water. II International Symposium - Chlorine dioxide: drinking water issues. Houston, USA. 